\title{
Neuroscience: Alloy for Early Childhood Education
}

\author{
CrossMark \\ Juana Maricela Quintana Loor a , Jessica Lourdes Arteaga Mera ${ }^{b}$, Luz Adriana Corrales Morenoc ${ }^{\text {, Josefa }}$ \\ Katiuska Toala Palma ${ }^{\mathrm{d}}$, Lubis Carmita Zambrano Montes ${ }^{\mathrm{e}}$
}

Manuscript submitted: 27 February 2020, Manuscript revised: 09 March 2020, Accepted for publication: 18 April 2020

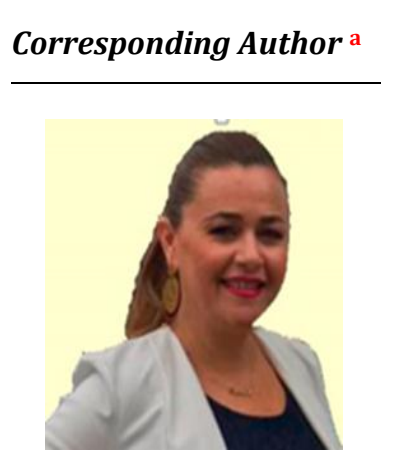

\begin{abstract}
It is intended to carry out a tour about the influence of neuroscience in early childhood education. It is important that all teachers, especially those working with infants, can know the fundamental principles of neuroscience and how the brain learns; thus have sufficient resources for decision making in school classrooms. This research paper attempts to make an introduction about the topic to be addressed and its focus on early childhood education.
\end{abstract}

\section{Keywords}

brain;

infant education;

learning;

memory;

neuroscience;

\section{Contents}

Abstract

1 Introduction.

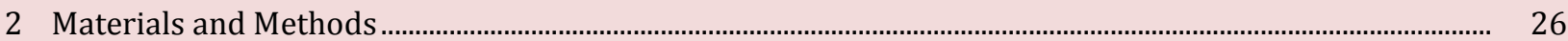

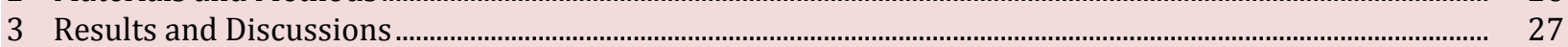

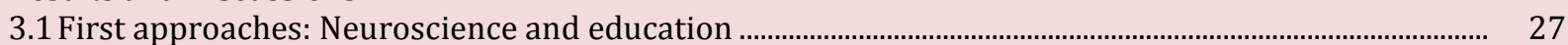

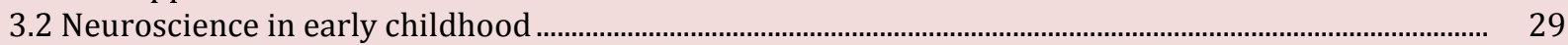

a Pontificia Universidad Católica del Ecuador, sede Manabí, Portoviejo, Ecuador

b Pontificia Universidad Católica del Ecuador, sede Manabí, Portoviejo, Ecuador

c Pontificia Universidad Católica del Ecuador, sede Manabí, Portoviejo, Ecuador

d Pontificia Universidad Católica del Ecuador, sede Manabí, Portoviejo, Ecuador

e Pontificia Universidad Católica del Ecuador, sede Manabí, Portoviejo, Ecuador 
Conclusion

Acknowledgments.

References

30

Biography of Authors

32

\section{Introduction}

For several authors, the study of neuroscience should not be reduced solely to the study of a discipline, on the contrary, it should be approached as a set of sciences that have the purpose of investigating the nervous system (Bullón et al., 2016). This vision is shared by other authors such as Arnay \& Burunat who add that: "the attempt to understand the nervous system responds to the interest of trying to understand how the human being relates to his environment and what explains his behavior." (Terigi, 2016).

Education is the process through which the person acquires a set of learning, values, and knowledge through formal or informal contexts, as mentioned by Jerome (1987), any experience through which the individual thinks, feels, or acts It can be considered part of education. Brígido (2006), is probably the one who offers a more complete definition of the term education:

[...] education means the formation of habits, of basic dispositions that determine how each one of us thinks, feels, and acts. This process of formation of habits and dispositions can be carried out in two ways: one intentional, conscious or explicit, and another tacit, latent, unintentional, unconscious (Brígido, 2006; Simbaña et al., 2017).

You can talk about a close relationship between the ultimate goal of education, the formation of knowledge that will allow the person to relate to their environment, the goal of neuroscience that seeks to understand how this relationship is produced from the physical. The relationship between education and neuroscience is not recent, dating back to the 40s of the last century (Andrade-Zambrano \& Yánez-García, 2016). By then, human behavior scholars tried to find explanations for various questions about intelligence and what are the main factors to explain it (Van Gelder, 1998).

At present it is possible to observe how great diversity of findings of cognitive studies has been incorporated in education, both to try to understand learning and teaching, and for the treatment of information, the proper design of curricular meshes, creation of tools learning and evaluation didactics (Picco \& Orienti, 2017). Despite the remarkable results of the approach between teaching and neuroscience, there are still important challenges to apply new findings of cognitive studies in the classroom (López-Escribano, 2007).

It is here that cooperation and joint work between educators and neuroscientists should seek to create synergies for the understanding of the teaching process. In this sense, some authors are more skeptical of the results, including Andrade-Zambrano \& Yánez-García (2016), who question the true contribution of neuroscience to education and propose the need to generate joint studies in that the results can be evidenced empirically. From a similar position, Arnay \& Buruna are more specific in the need for research to point to the clarification of the relationship between education and the nervous system (Terigi, 2016). The study is novel since there is no research record about the impact of neuroscience in early childhood education in the province of Manabí. Therefore, research work is important for the Inter-American Educational Unit of the city of Bahía de Caráquez.

\section{Materials and Methods}

In the investigation the inductive-deductive method was used, which allowed us to investigate with a qualitative, non-experimental approach, no variables were used to make statistical measurements. Neuroscience approaches in the area of early childhood education were analyzed and allowed to obtain resources and information for development from the analysis of documents as a scientific research method (Schmitz \& Hof, 2005; Beaty, 2015; Izuma, 2012; Prendergast et al., 2014). There has been a thorough literature review on the subject being studied, being able to appreciate the historical evolution in the field of neurosciences and its influence in the Ecuadorian educational context especially in the province of Manabí. 


\section{Results and Discussions}

\subsection{First approaches: Neuroscience and education}

Despite the skeptical visions of the relationship between education and neurosciences, many of the criticisms have been able to be answered through technological advances. With the use of non-invasive imaging equipment such as CT scan (computerized axial tomography), Magnetic Resonance Imaging (MRI), and spectrometers, among others, it has been possible to verify human learning processes mechanistically (Bullón et al., 2016). According to this author, it can be seen among the main findings shown in figure 1.

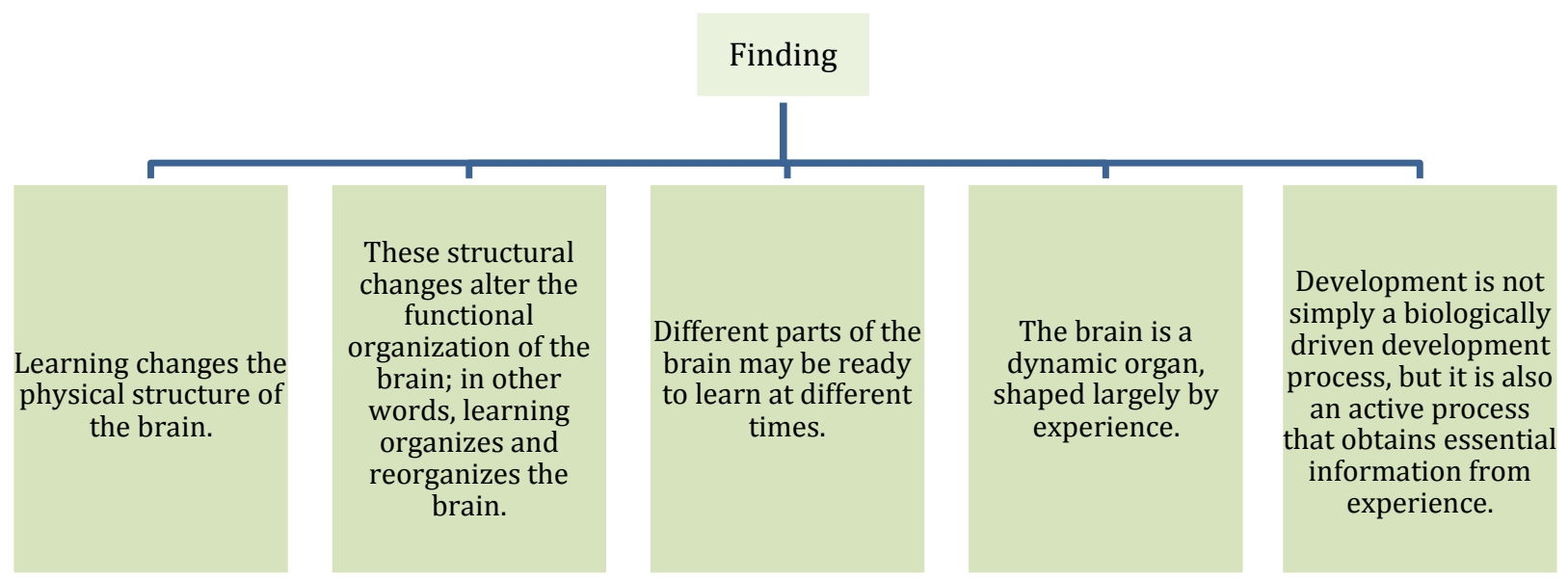

Figure 1. Main findings

Source: Own elaboration taking information contained in Salas (2003) (Bullón et al., 2016)

It is possible to understand the findings of Salas (2003), as an attempt to make the postulates of Caine et al. (2016), who synthesized the investigation of a set of brain learning principles that, at the time contributed to try to understand the learning processes (Bullón et al., 2016). These principles have been nourished over time thanks to new contributions from different branches of knowledge such as cognitive psychology, stress theory, and creativity (Caine et al., 2016). Next, the principles of brain learning developed are analyzed.

For many authors, including Andrade-Zambrano \& Yánez-García (2016), one of the most powerful features of the brain is its ability to function at many levels and to adapt its functioning according to emerging needs. In this sense, it can be mentioned that thoughts, emotions, imagination, predispositions, and physiology operate concurrently and interactively to the extent that the entire system interacts with its surroundings (Bullón et al., 2016).

Human beings begin to be configured as their brains interact with their early environment and the actors that compose it, that is, the brain changes in response to interaction with others (Seufert, 2003; Schnotz \& Bannert, 2003; Lin et al., 2003; Kirschner, 2002). Salas (2003), in this sense, concludes that part of the identity depends on the establishment of a community and the finding of ways to belong to it. Therefore, learning is deeply influenced by the nature of the social relationships within which people find themselves (Bullón et al., 2016). The eagerness to find meaning is not a new condition, it is born with it and feeds based on experiences, goals, and values. While our perception of what generates security may change throughout life, the structures that support the response system remain.

Principle number four is closely related to the previous point and has to do with certain guidelines, understanding them as a set of directions generated from the experience. The brain automatically records what seems familiar from previous experiences and knowledge. Salas (2003), offers an example to take this principle to the classroom by saying that: "an effective education should allow students to formulate their understanding guidelines” (Bullón et al., 2016).

Loor, J. M. Q., Mera, J. L. A., Moreno, L. A. C., Palma, J. K. T., \& Montes, L. C. Z. (2020). Neuroscience: alloy for early childhood education. International Journal of Health Sciences, 4(1), 25-32. https://doi.org/10.29332/ijhs.v4n1.421 
The process through which the brain stores and builds knowledge is greatly influenced by an emotional component. The relationship is so close that it is said that emotions and thoughts are molded to the point that they can hardly be separated. It is more than evident then that an emotional climate is indispensable so that the classrooms can be spaces of the true generation of knowledge and recreation for the students (Mendoza et al., 2019; Johnson \& Justice, 1983; Holcomb \& Mcpherson, 1994).

The doctrine of the "dual brain" in which particular characteristics are attributed to each hemisphere of the brain has illustrative purposes, but the reality is that in each activity the two hemispheres perform tasks together. It is a mistake to conceive of learning as a uniquely emotional or rational process that is related to a certain hemisphere of the brain. Understanding the complementarity of the two hemispheres for the development of tasks should lead us to think about strategies for classrooms to be spaces of integral stimulation.

The brain can absorb information on two levels, the first one, from a conscious dimension and the second from the peripheral perception, as mentioned by Salas (2003): "Even the unconscious signals that reveal inner attitudes and beliefs, they have a powerful effect on students". Those who have the opportunity to be educators have the responsibility of maintaining attention to the entire process of education, both the knowledge imparted directly and those that are generated from the students' perception. How? "Properly designing the context, incorporating reflection and metacognitive activities, and providing the means to help students creatively expand ideas, skills and experiences" (Bullón et al., 2016).

The brain has a set of systems to remember information that is not only structured through a linear form of memory, but there are also different types such as that system organized from positive or negative conditions. In this sense, Squire et al. (1993), analyzed that other types of memory have also been identified, for example, those involved in skills and habits, preparation, conditioning and perhaps the ability to acquire generic knowledge at the level of categories " (Squire et al., 1993).

Understanding the importance of principles is vital if we want to get students to learn effectively. As teachers, you must have the obligation to build environments in which students feel challenged and motivated to learn without falling into arbitrariness and abuse of power. Salas (2003), is emphatic in mentioning the low threat is not, however, synonymous with simply "feeling good." The essential element of a perceived threat is a feeling of helplessness or fatigue. The original tension and anxiety are inevitable and should be expected in genuine learning" (Bullón et al., 2016).

The principle invites us to think about the peculiarities of student learning, an important corollary is to appreciate that students are different and that they need to choose, while they are sure that they are exposed to a multiplicity of stimuli (Caine et al., 2016). Multiple intelligences are, therefore, characteristics of what it means to be human (Bullón et al., 2016). Figure 2 shows the principles of neuroscience, seen by some actors.

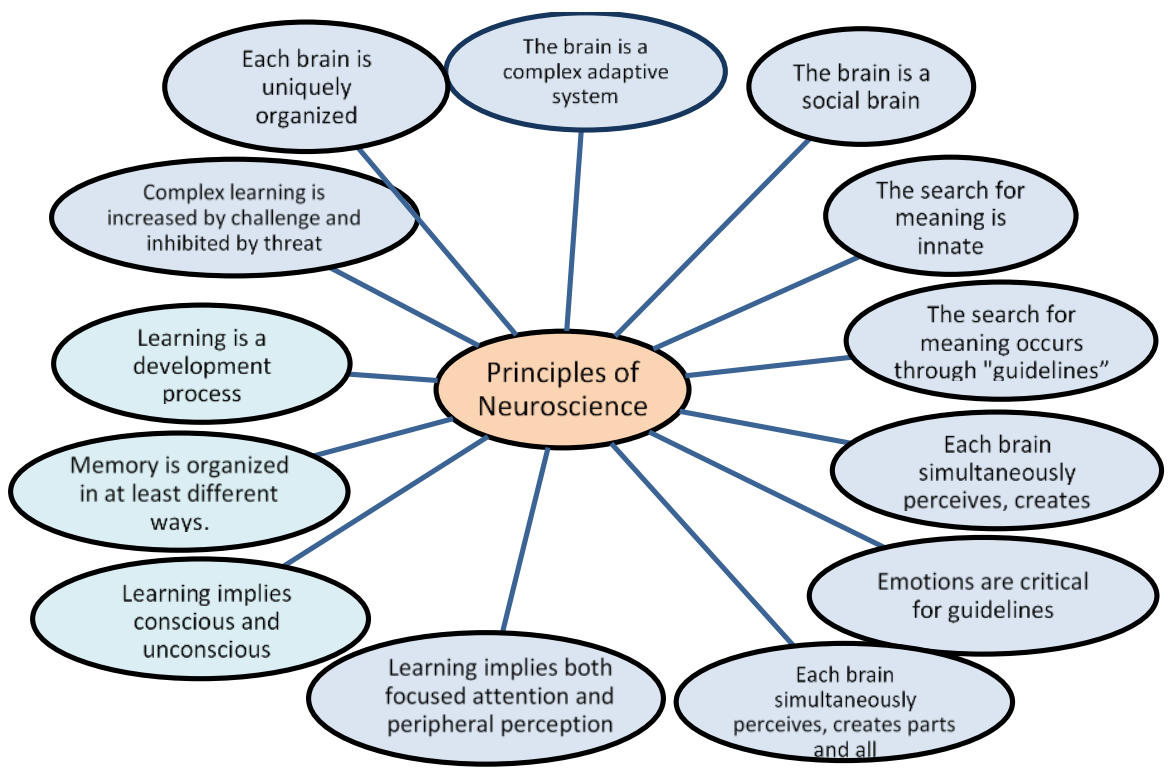

Figure 2. Principles of neuroscience 


\subsection{Neuroscience in early childhood}

Childhood education Early education perceives the child as a being that shows individual characteristics, appropriate and that act in a particular way in its development, therefore, it is a unique child biologically and that both psychically and socially also It turns out to be different and unrepeatable to the rest of their peers, so their development is continuous and fast (Moya \& Rotondaro, 2015) is why the actions aimed at their training must be thought, precisely it is the time that children learn to communicate, Interact and play with your peers. At the beginning of the 21st century, several authors contribute a new approach to the definition of early childhood with the study of neurosciences, considered a set of disciplines that analyze the entire structure and function of the brain, (Piñeiro \& Diaz, 2017). Analyzing this contribution the figure of the teacher is a point of reference for learning and even of affections, the teacher, from different activities, motivates children in the new stage of learning away from home.

It is necessary that those responsible for providing early childhood education incorporate neurosciences and Tics into their strategies. As an integrating part of the children's education cycle. The sensory apparatus is nourished by perceptions and the information received allows us to know what each person becomes (Sturges, 2015), therefore, social existence and interaction with other human beings are essential and important for integral development.

Unesco (2015), reports that in the new educational goals 2030 the role of dedication to early childhood education is emphasized, and it is indicated that "it lays the foundations of lifelong learning and promotes the well-being of children and girls, and their progressive preparation for admission to primary school" (RobledoCastro, 2019). Educational centers have the responsibility of guaranteeing the integral health and safety of children.

The investigation of this work generates expectations because the main results show that neuroscience influences the development of infants. Teachers of educational institutions that offer initial education become the space that should guarantee early stimulation. It is provided with a small valuable description by several authors about neurosciences and early childhood education.

Beyond the biological that is undoubtedly important to know, some authors such as Piñeiro, R. \& Díaz, T; Ruano, AF and Terigi, F. have contributed that the brain is an organ besides complex, amazing and very versatile because it is responsible for learning, cognition, memory, attention and even emotions. The brain has other fundamental characteristics that distinguish it; In addition to multiple intelligences. On the other hand, the emotions which keep the brain curious and attentive are necessary to communicate, they are essential because in the cognitive and emotional processes. It is also important to mention some contributions from Sturges, P .; Simbaña, V., Jaramillo, L., and Vinueza, which mentions that brain development is influenced both by biological factors and by the interrelation with external factors that are represented by stimuli coming from children or people.

\section{Conclusion}

Throughout this document, it has been possible to determine the existence of great contributions arising from the relationship between neurosciences and early childhood education. First, it has been established that neuroscience is not only a discipline, but that it is a set of sciences that seek to study the nervous system. On the other hand, that education is a process of obtaining knowledge, values, and learning either in formal and informal spheres, therefore, education and neuroscience are closely connected. This study shows us that our brain is a complex system, but that it is capable of adapting to different environments, for this reason, it needs to be stimulated correctly. Thanks to these principles, today we know that our brain, like us, is social, that it is different from that of others, and that it responds better to challenges. On the other hand, the key to reaching our students is to understand the importance of the meaningful search that lies within each one of them and that the teaching is not only transmitted rationally but also emotionally.

\section{Acknowledgments}

The author expresses her gratitude to the IJHS team and collaborators for the editorial boards, as well as for their valuable time, support, and advice in this study.

Loor, J. M. Q., Mera, J. L. A., Moreno, L. A. C., Palma, J. K. T., \& Montes, L. C. Z. (2020). Neuroscience: alloy for early childhood education. International Journal of Health Sciences, 4(1), 25-32. https://doi.org/10.29332/ijhs.v4n1.421 


\section{References}

Andrade-Zambrano, CD, \& Yánez-García, BM (2016). Neurosciences, education and educational practices. Santiago, 166-179.

Beaty, R. E. (2015). The neuroscience of musical improvisation. Neuroscience \& Biobehavioral Reviews, 51, 108117. https://doi.org/10.1016/j.neubiorev.2015.01.004

Brigido, S. A. (2006). The use of an acellular dermal regenerative tissue matrix in the treatment of lower extremity wounds: a prospective 16-week pilot study. International wound journal,3(3), 181-187. https://doi.org/10.1111/j.1742-481X.2006.00209.x

Bullon, P., Marin-Aguilar, F., \& Roman-Malo, L. (2016). AMPK/mitochondria in metabolic diseases. In AMPactivated Protein Kinase (pp. 129-152). Springer, Cham. https://doi.org/10.1007/978-3-319-43589-3_6

Caine, R., Caine, G., McClintic, C. y \& Klimek, K. (2016).12 Brain- Mind Learning Pinciples in Action. United States of America: Corwin.

Holcomb, P. J., \& Mcpherson, W. B. (1994). Event-related brain potentials reflect semantic priming in an object decision task. Brain and cognition, 24(2), 259-276. https://doi.org/10.1006/brcg.1994.1014

Izuma, K. (2012). The social neuroscience of reputation. Neuroscience research, 72(4), 283-288. https://doi.org/10.1016/j.neures.2012.01.003

Jerome, A. (1987). La importancia de la educación. Barcelona: Paidós Ibérica.

Johnson, R. D., \& Justice, J. B. (1983). Model studies for brain dialysis. Brain research bulletin, 10(4), 567-571. https://doi.org/10.1016/0361-9230(83)90156-9

Kirschner, P. A. (2002). Cognitive load theory: Implications of cognitive load theory on the design of learning. https://doi.org/10.1016/S0959-4752(01)00014-7

Lin, Y. G., McKeachie, W. J., \& Kim, Y. C. (2003). College student intrinsic and/or extrinsic motivation and learning. Learning and individual differences, 13(3), 251-258. https://doi.org/10.1016/S1041$6080(02) 00092-4$

López-Escribano, C. (2007). Contributions of neuroscience to the diagnosis and educational treatment of developmental dyslexia. Rev Neurol , 44 (3), 173-80.

Mendoza, L. R. M., Martinez, M. E. M., \& Suarez, A. M. S. (2019). The brain as a fundamental axis in learning process. International Research Journal of Engineering, IT \& Scientific Research, 5(4), 38-45. https://doi.org/10.21744/irjeis.v5n4.689

Moya, M. V. \& Rotondaro, F. (2015). La educación Infantil que queremos: investigaciones y experiencias. Revista de la Facultad de Educación de Albacete, 30(2), 1-9.

Picco, S. y \& Oriento, N. (2017). Didactica y Curriculum. Aportes teóricos y practicos para pensar e intervenir en las practicas de la enseñanza. Chile: Editorial de la Universidad Nacional de la Plata.

Piñeiro, R., \& Díaz, T. (2017). Factores que influyen en el neurodesarrollo de 0 a 6 años.

Prendergast, B. J., Onishi, K. G., \& Zucker, I. (2014). Female mice liberated for inclusion in neuroscience and biomedical research. Neuroscience \& Biobehavioral Reviews, 40, 1-5. https://doi.org/10.1016/j.neubiorev.2014.01.001

Robledo-Castro, C., Amador-Pineda, LH, \& Ñáñez-Rodríguez, JJ (2019). Public policies and educational policies for early childhood: challenges for the training of early childhood educators. Revista Latinoamericana de Ciencias Sociales, Niñez y Juventud , 17 (1), 169-191. http://dx.doi.org/10.11600/1692715x.17110

Salas Silva, R. (2003). ¿ La educación necesita realmente de la neurociencia?. Estudios pedagógicos (Valdivia), (29), 155-171.

Schmitz, C., \& Hof, P. R. (2005). Design-based stereology in neuroscience. Neuroscience, 130(4), 813-831. https://doi.org/10.1016/j.neuroscience.2004.08.050

Schnotz, W., \& Bannert, M. (2003). Construction and interference in learning from multiple representation. Learning and instruction, 13(2), 141-156. https://doi.org/10.1016/S09594752(02)00017-8

Seufert, T. (2003). Supporting coherence formation in learning from multiple representations. Learning and instruction, 13(2), 227-237. https://doi.org/10.1016/S0959-4752(02)00022-1

Simbaña Gallardo, V., Jaramillo Naranjo, L., \& Vinueza Vinueza, S. (2017). Durkheim's contribution to the Sociology of Education. Sophia, Collection of Philosophy of Education, (23), 83-89.

Squire, L. R., Knowlton, B., \& Musen, G. (1993). The structure and organization of memory. Annual review of psychology, 44(1), 453-495. 
Sturges, P. (2015). Avances de la neurociencia y sus implicaciones para la ciencia de la información. $E l$ profesional de la información, 24(2), 168-175.

Terigi, F. (2016). On school learning and neuroscience. Educational proposal, (46), 50-64.

Van Gelder, T. (1998). The dynamical hypothesis in cognitive science. Behavioral and brain sciences, 21(5), 615-628. https://doi.org/10.1017/S0140525X98001733

Loor, J. M. Q., Mera, J. L. A., Moreno, L. A. C., Palma, J. K. T., \& Montes, L. C. Z. (2020). Neuroscience: alloy for early childhood education. International Journal of Health Sciences, 4(1), 25-32. https://doi.org/10.29332/ijhs.v4n1.421 


\section{Biography of Authors}

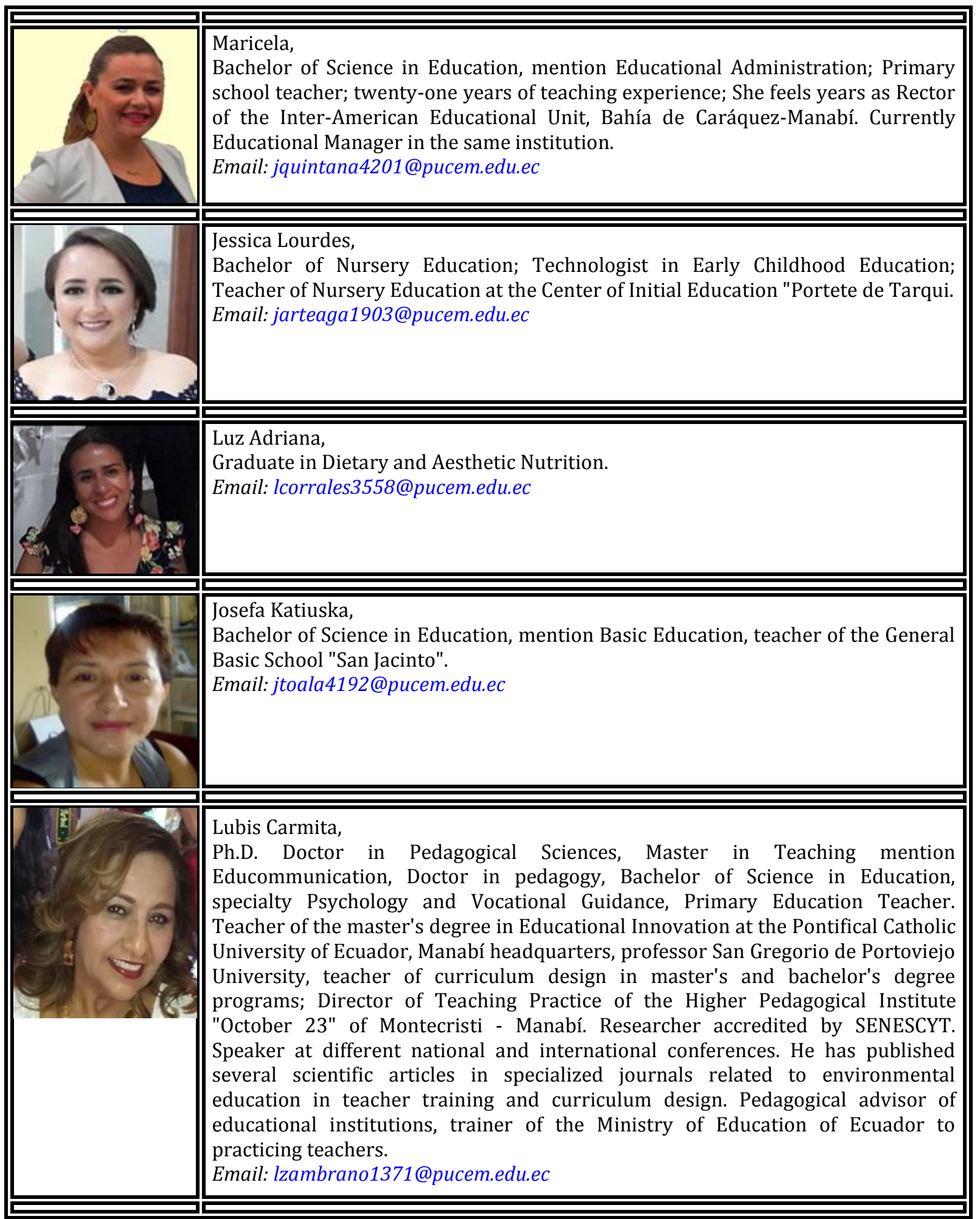

